\title{
PEMBELAJARAN PUISI RAKYAT PADA PELAKSANAAN KURIKULUM 2013 DI KELAS VIIE SMP NEGERI 1 SUKASADA
}

\author{
Gst A.A Dyah Puspitasari ${ }^{1}$, Made Astika ${ }^{2}$, I Wayan Wendra ${ }^{3}$ \\ Prodi Pendidikan Bahasa Indonesia, Jurusan Bahasa Sastra Indonesia dan \\ Daerah, Fakultas Bahasa dan Seni, Universitas Pendidikan Ganesha \\ Singaraja, Indonesia
e-mail:puspitadyah072@gmail.com ${ }^{1}$, made.astika@undiksha.ac.id ${ }^{2}$, wayan wendra@yahoo.com ${ }^{3}$

\begin{abstract}
ABSTRAK
Penelitian ini bertujuan untuk mendeskripsikan (1) pelaksanaan pembelajaran puisi rakyat pada pelaksanaan Kurikulum 2013 di kelas VIIE SMP Negeri 1 Sukasada, (2) penggunaan teks dalam pembelajaran puisi rakyat pada pelaksanaan Kurikulum 2013 di kelas VIIE SMP Negeri 1 Sukasada, dan (3) penggunaan media dalampembelajaran puisi rakyat pada pelaksanaan Kurikulum 2013 di kelas VIIE SMP Negeri 1 Sukasada. Penelitian ini menggunakan rancangan penelitian deskriptif kualitatif.Subjek dalam penelitian ini adalah guru Bahasa IndonesiaSMP Negeri 1 Sukasada. Objek penelitian ini adalah(1) pelaksanaan pembelajaran puisi rakyat pada pelaksanaan Kurikulum 2013,(2) penggunaan teks dalam pembelajaran puisi rakyat pada pelaksanaan Kurikulum 2013 di kelas VIIE SMP Negeri 1 Sukasada, dan (3) penggunaan media dalam pembelajaran puisi rakyat pada pelaksanaan Kurikulum 2013 di kelas VIIE SMP Negeri 1 Sukasada.Data dikumpulkan dengan metode observasidan wawancara (semiterstruktur).Tahapananalisis data meliputi reduksi data, penyajian data, dan penyimpulan. Hasil penelitian menunjukan bahwa (1) pelaksanaan pembelajaran puisi rakyat belum sesuai dengan isi skenario pembelajaran dan Permendikbud No. 81A Tahun 2013, (2) penggunaan teks belum sesuai dengan empat tahapan pembelajaran Bahasa Indonesia berbasis teks berdasarkan atas aturan Kemendikbud Tahun 2013, (3) penggunaan media sangat terbatas tidak sesuai dengan tuntutan Kurikulum 2013.
\end{abstract}

Kata kunci: Pembelajaran puisi rakyat, Kurikulum 2013.

\begin{abstract}
This research aims to describe (1) implementation of folksy poetry learning at implementation curriculum 2013 in VIIE Class at SMP Negeri 1 Sukasada, (2) text utilization in learning folksy poetry at implementation in curriculum 2013 in VIIE class SMP Negeri 1 Sukasada, and (3) media utilization in learning folksy poetry at implementation curriculum 2013 in VIIE class SMP Negeri 1 Sukasada. this research use qualitative descriptive plan research. The subject in this research was Indonesian language teacher in SMP Negeri 1 Sukasada. The object in this research was (1) implementation learning folksy poetry at curriculum 2013, (2) text utilization in learning folksy poetry at implementation in curriculum 2013 in VIIE class SMP Negeri 1 Sukasada, and (3) media utilization in learning folksy poetry at implementation curriculum 2013 in VIIE class SMP Negeri 1 Sukasada. The data in this research be gathered use
\end{abstract}


observation and interview methods (semi-structure). The step of data analysis was reduce data, presentation data, and resume. Result of this research was shows that (1) the implementation on folksy poetry learning wasn't appropriate with the learning scenario and Permendikbud No. 81A in 2013, (2) text utilization wasn't appropriate with four step in Indonesian Language based on text learning repose on rules Kemendikbud 2013 . (3) media utilization very limited not in accordance with the demands of the 2013 curriculum.

Keywords:learning folksy poetry, curriculum in 2013,

\section{PENDAHULUAN}

Pembelajaran puisi rakyat
merupakan pembelajaran yang
dihadirkan dalam Kurikulum 2013
hasil revisi kurikulum pada tahun
2016. Pembelajaran ini dihadirkan
pada semester dua kelas VII di
SMP. Menurut Sugiarto (2006: 19)
sastra melayu klasik atau puis rakyat merupakan salah satu khazanah kebudayaan Indonesia yang kini hampir dilupakan oleh generasi muda. Hal tersebut dikarenakan sebagian besar puisi rakyat berupa sastra lisan sehingga upaya pewarisan sastra jenis ini relatif lebih sulit dibanding dengan karya sastra tetulis/tercetak.

Dalam kesenjangan tersebut peran Kurikulum 2013 dalam menghadirkan pembelajaran puisi rakyat ke dalam pembelajaran Sekolah Menengah Pertama sangat tepat. Oleh karena itu, pembelajaran ini dihadirkan karena di dalamnya kaya akan nilai moral, agama, dan budi pekerti sehingga dalam proses pembelajaran berdasarkan Kurikulum 2013 diharapkan tercipta pembelajaran yang aktif melalui kegiatan-kegiatan pembelajaran yang berpusat pada siswa.

Dalam

kegiatan pembelajaran, tentunya faktor utama yang berperan penting dalam menyukseskan pembelajaran adalah guru. Guru tidak hanya berperan sebagai model pembelajaran bagi siswa tetapi juga sebagai pengelola pembelajaran. Tanpa adanya guru, tentunya pelaksanaan pembelajaran tidak akan berlangsung dengan baik karena sebaik apapun prasarana di sekolah jika kualitas guru rendah maka hasil yang didapat tentunya rendah. Maka dari itu guru adalah faktor utama yang berpengaruh dalam pelaksanaan pembelajaran.

Pelaksanaan pembelajaran merupakan tahap implementasi atau tahap penerapan strategi yang telah dirancang oleh guru untuk mencapai tujuan pengajaran. Dalam Permendikbud No. 81A Tahun 2013 tentang Implementasi Kurikulum Pedoman Umum Pembelajaran menyatakan bahwa pelaksanaan pembelajaran untuk setiap pertemuan merupakan langkahlangkah guru dalam membuat peserta didik aktif belajar.Sependapat dengan hal tersebut Midiastini (2014: 27) menyatakan pelaksanaan pembelajaran merupakan peristiwa transformasi sosial yang bermuatan nilai, kebiasaan, pengetahuan, bahkan juga dapat dimaknai sebagai proses pembentukan sikap dari guru kepada peserta didik. Berdasarkan pendapat tersebut dapat ditegaskan bahwa pelaksanaan pembelajaran merupakan implementasi penerapan dari desain perencanaan yang dibuat oleh guru.

Berdasarkan isi lampiran Bab IV Permendikbud No. 81A Tahun 2013 tentang Implementasi 
Kurikulum Pedoman Umum Pembelajaran, dalam pelaksanaan pembelajaran ada beberapa kegiatan yang harus dilakukan oleh guru yaitu, kegiatan pendahuluan, kegiatan inti (mengamati, menanya, mengumpulkan informasi, mengolah informasi,dan mengomunikasikan), terakhir kegiatan penutup. Ketiga kegiatan ini merupakan kegiatan pokok yang harus dilakukan guru dalam melaksanakan kegiatan pembelajaran.

Pelaksanaan pembelajaran berdasarkan Kurikulum 2013 menuntut adanya perubahan. Kurikulum 2013 menerapkan pembelajaran berbasis teks. Dalam Kurikulum 2013 teks tidak diartikan sebagai bentuk bahasa tulis. Mashun (2013: 13) menyatakan bahwa teks adalah ungkapan pikiran manusia yang lengkap di dalamnya terdapat situasi dan konteks. Itu artinya dalam belajar bahasa Indonesia tidak hanya sekadar memakai bahasa Indonesia sebagai alat komunikasi, tetapi perlu juga mengetahui makna atau bagaimana memilih kata yang tepat sesuai dengan konteksnya.Berdasarkan prawacana pembelajaran teks (Kemdikbud, 2013: vi) ada empat tahapan pembelajaran berbasis teks yang harus di tempuh, yaitu (1) tahap pembangunan konteks. Tahap ini merupakan langkah awal yang dilakukan oleh guru bersama siswa untuk mengarahkan pemikiran ke dalam pokok persoalan yang dibahas pada setiap pelajaran. (2) tahap pemodelan teks. Tahap yang berisi pembahasan teks yang disajikan sebagai model pembelajaran dilaksanakan pada kegiatan ke 2.Ada tiga tahapan strategi pemodelan teks dalam proses menulis yaitu membaca teks model, menganalisis teks model, dan berlatih menulis dengan meniru kontruksi teks model.(3) tahap pembuatan teks secara bersamasama. Pada tahap ini semua siswa dan guru sebagai fasilitator menyusun kembali teks seperti yang ditunjukan pada model. (4) tahapan pembuatan teks secara mandiri. Pada tahap ini merupakan kegiatan belajar mandiri.Siswa diharapkan dapat mengaktualisasikan diri dengan menggunakan dan mengkreasikan teks sesuai dengan jenis dan ciri-ciri seperti yang ditunjukan pada model.

Berdasakan empat tahapan tersebut, teks idealnya berawal dari memahami teks, mengolah teks, mendiskusikan teks, mengubah teks, dan dikhiri memproduksi teks. Pembelajaran berbasis teks dalam mata pelajaran bahasa Indonesia lebih menekankan pada siswa untuk memahami berbagai jenis teks dan menuntut siswa untuk mahir menulis seperti halnya teks puisi rakyat.

Dalam pelaksanaan pembelajaran Kurikulum 2013, guru tidak hanya dituntut menerapkan pembelajaran berbasis teks namun guru juga diminta untuk kreatif dalam menggunakan media pada kegiatan pembelajaran. Menurut Asyhar (2012: 25) media merupakan segala sesuatu yang dapat membawa informasi atau pesan dan interaksi dalam proses pembelajaran. Itu artinya media adalah suatu alat yang digunakan guru sebagai sarana untuk menyampaikan suatu pesan atau informasi dari sumber ke penerimanya. Penggunaan media pembelajaran bertujuan agar siswa dapat berpikir kreatif, berpikir kritis, memiliki kepekaan, dan mempertajam daya pikir dan imajinasi.

Media pembelajaran memiliki beberapa kriteria atau jenis mulai dari yang sangat sederhana hingga yang kompleks dan rumit. 
Berdasarkan jenisnya tentunya dalam melaksanakan pembelajaran puisi rakyat pemilihan media yang cocok digunakan sangat berpengaruh dalam keberlangsungan

pembelajaran.Menurut Asyhar (2012: 44-55) media visual merupakan salah satu jenis media yang digunakan hanya mengandalkan indera penglihatan semata-mata dari siswa. Dengan media ini, pengalaman belajar yang di alami oleh siswa sangat tergantung pada kemampuan penglihatannya.Dapat ditegaskan media visual merupakan salah satu jenis media yang sangat mudah digunakan dan tentunya media ini sangat membantu dalam proses pembelajaran puisi rakyat karena media visual merupakan media yang informasinya dapat dilihat. Media ini paling sering digunakan oleh guru biasanya berupa buku dan modul di dalam proses pembelajaran.

Tidak hanya media visual, media audiovisual merupakan salah satu media pembelajaran yang sangat baik untuk meransang motivasi dan minat belajar pada siswa. Dalam memahami pembelajaran puisi rakyat, tidak hanya dapat disajikan visual mengenai latar belakang pengarang juga dapat menyajikan unsur audio yang berupa pembacaan puisi rakyat. Penggunaan media audiovisual pada pembelajaran puisi rakyat tentunya akan menimbulkan motivasi dan gairah belajar pada siswa.Menurut Asyhar (2012) media Audio-visual adalah jenis media yang digunakan dalam kegiatan pembelajaran dengan melibatkan pendengaran dan penglihatan sekaligus dalam satu proses atau kegiatan. Pesan dan informasi yang dapat disalurkan melalui media ini dapat berupa pesan verbal dan nonverbal yang menghandalkan baik penglihatan maupun pendengaran.

Maka dapat ditegaskanmedia merupakan komponen yang erat kaitannya dengan materi ajar yang digunakan guru. Sebagai alat perantara dalam menyampaikan materi, proses pemilihan media pun sangat penting untuk keberhasilan pembelajaran. Pemilihan materi ajar dan penggunaan media dengan tepat akan berdampak dalam meningkatkan proses interaksi belajar-mengajar. Itu artinya guru dalam melaksanakan pembelajaran seperti mengajarkan materi puisi rakyat setidaknya harus mampu memberikan media yang sesuai dengan pembelajaran, agar terciptanya pembelajaran yang menarik dan mudah dipahami siswa sehingga proses interaksi belajarmengajar menjadi meningkat.

Berdasarkan pemaparan
tersebut peran guru dalam
keberhasilan pelaksanaan Kurikulum
2013 sangatlah besar. Guru sebagai
fasilitator tidak hanya membimbing
siwa dalam kegiatan pembelajaran
namun guru juga dituntut untuk
mampu menerapkan pembelajaran
berbasis teks dan menggunakan
media yang sesuai dengan materi
yang diajarkan. Itu merupakan salah
satu syarat terwujudnya
pembelajaran sesuai dengan
Kurikulum 2013.

Meskipun semua jenjang pendidikan di Indonesia telah dianjurkan menerapkan Kurikulum 2013 namun masih banyak sekolah yang belum sepenuhnya optimal dalam menerapkan Kurikulum 2013. Terbukti pada tahap pelaksanaan pembelajaran guru belum sepenuhnya menjalankan pembelajaran bahasa Indonesia berdasarkan Kurikulum 2013 secara optimal. Masih ada beberapa guru 
memberikan materi dan metode ceramah sehingga dalam pelaksanaan pembelajaran kurang efektif, dan seringkali membuat siswa mengantuk. Tidak hanya itu masih ada beberapa guru yang kurang paham dengan penggunaan teks yang sesuai dengan Kurikulum 2013. Penggunaan media pun sama, sebagaian besar guru mengajar dengan gaya berceramah dan minim menggunakan media pembelajaran. Hal tersebut juga yang menyebabkan proses pembelajaran kurang menarik dan membuat daya serap siswa pada pembelajaran tidak optimal

\section{Berdasarkan permasalahan} di atas, tujuan penelitian ini dilakukan untuk mengetahui bagaimana pelaksanaan, penggunaan teks, dan penggunaan media dalam pembelajaran puisi rakyat pada pelaksanaan Kurikulum 2013 di kelas VIIE SMP Negeri 1 Sukasada.Tujuan yang ingin dicapai pada penelitian ini adalah untuk mendeskripsikan pelaksanaan pembelajaran puisi rakyat pada pelaksanaan Kurikulum 2013 di kelas VIIE SMP Negeri 1 Sukasada, mendeskripsikan penggunaan teks dalam pembelajaran puisi rakyat pada pelaksanaan Kurikulum 2013, dan mendeskripsikan penggunaan media dalam pembelajaran puisi rakyat pada pelaksanaan Kurikulum 2013 di kelas VIIE SMP Negeri 1 Sukasada. Adapun mamfaat yang diharapkan dari penelitian ini yaitu ada dua, mamfaat teoritis yaitu mengembangkan teori pembelajaran puisi rakyat dan mamfaat praktis yaitu guru dapat meningkatkan kualitas pelaksanaan pembelajaran sesuai Kurikulum 2013.

\section{METODE}

Tercapai tidaknya tujuan penelitian, sangat bergantung pada metode yang digunakannya.Metode penelitian yang digunakan dalam penelitian ini mencakup (1) rancangan penelitian, (2) subjek dan objek penelitian, (3) metode dan instrumen pengumpulan data, dan (4) teknik analisis data.Menurut Wendra (2011: 32)rancangan penelitian merupakan strategi mengatur latar (setting) penelitian agar peneliti memperoleh data yang tepat/valid sesuai dengan karakteristik variabel dan tujuan penelitian. Pada penelitian ini, peneliti ingin mendapat gambaran yang jelas mengenai pelaksanaan pembelajaran, penggunaan teks, penggunaan media dalam pembelajaran puisi rakyat pada pelaksanaan Kurikulum 2013 di kelas VIIE SMP Negeri 1 Sukasada. Oleh karena itu, agar tujuan penelitian tercapai, rancangan penelitian yang digunakan adalah rancangan deskriptif kualitatif. Subjek dalam penelitian ini adalah guru Bahasa Indonesiadi SMP Negeri 1Sukasada. Objek dalam penelitian ini adalah pelaksanaan pembelajaran, penggunaan teks, dan penggunaan media dalam pembelajaran puisi rakyat pada pelaksanaan Kurikulum 2013 di kelas VIIE SMP Negeri 1 Sukasada.

Pada pengumpulan data penelitian, peneliti menggunakan metode observasi, dan wawancara (semiterstruktur). Metode observasi digunakan untuk menjawab dari permasalahan yang diteliti, yaitu mengenai pelaksanaan pembelajaran, penggunaan teks, dan penggunaan mediadalam pembelajaran puisi rakyat pada pelaksanaan Kurikulum 2013 di kelas VIIE SMP Negeri 1 Sukasada. Penggunaan metode wawancara (semiterstruktur) merupakan lanjutan dari metode observasi. Dalam metode ini, digunakan untuk mencari data yang tidak didapatkan melalui observasi. Instrumen yang 
digunakan yaitu: catatan lapangan (tabel checklist), danpedoman wawancara.Data-data yang telah dikumpulkan, selanjutnya dianalisis menggunakan teknik analisis data deskriptif kualitatif yang meliputi deskripsi data, penyajian data, dan penarikan simpulan.

\section{HASIL DAN PEMBAHASAN}

$\begin{array}{cc}\text { Hasil } & \text { penelitian ini } \\ \text { mencangkup } & \text { mengenai(1) } \\ \text { pelaksanaan pembelajaran puisi } & \text { pakyat dalam pelaksanaan Kurikulum } \\ \text { rakyan } & \\ 2013 \text { di kelas VIIE SMP Negeri } 1\end{array}$ Sukasada, (2) penggunaan teks dalam pembelajaran puisi rakyat pada pelaksanaan Kurikulum 2013 di kelas VIIE SMP Negeri 1 Sukasada, dan (3) penggunaan media dalam pembelajaran puisi rakyat pada pelaksanaan Kurikulum 2013 di kelas VIIE SMP Negeri 1 Sukasada. Pelaksanaan pembelajaran puisi rakyat dalam pelaksanaan Kurikulum 2013 di kelas VIIE SMP Negeri 1 Sukasada belum sesuai dengan Permendikbud No. 81A Tahun 2013. Hal tersebut terlihat pada kegiatan inti dan penutup. Pada kegiatan inti pada saat mengamati, guru lebih sering memberikan teknik ceramah sehingga siswa dalam hal mengamati, lebih banyak mengamati penjelasan yang diberikan oleh guru. Sedangkan pada kegiatan menanya, siswa di dalam pembelajaran kurang aktif bertanya, sehingga proses pembelajaran pada kegitan inti tersebut belum sesuai dengan Permendikbud No 81A Tahun 2013. Pada kegiatan penutup sama halnya dengan kegiatan inti belum sesuai karena pada kegiatan ini guru jarang menyimpulkan atau memberikan penilaian mengenai hasil kegiatan pembelajaran yang dilaksanakan.
Selain itu, materi pembelajaran yang diberikan belum maksimal diajarkan. karena, guru lebih banyak mengajarkan materi pantun daripada syair dan gurindam.

Penggunaan teks dalam kegiatan pembelajaran puisi rakyat belum sesuai dengan empat tahapan pembelajaran berbasis teks pada umumnya. Hal tersebut terlihat pada tahap pembuatan teks secara mandiri, kegiatan tersebut belum terlaksana dengan baik karenakehabisan waktu dalam melaksanakan pembelajaran. Itu berarti dalam pelaksanaan kegiatan pembelajaran guru belum mampu mengelola waktu.

\begin{tabular}{lr}
\multicolumn{2}{c}{ Penggunaan media yang } \\
digunakan dalam & kegiatan \\
pembelajaran,ditemukan & bahwa \\
guru masih & sangat \\
terbatasmenggunakan & media
\end{tabular} terbatasmenggunakan media Kurikulum 2013. Hal itu karena guru lebih banyak menggunakan media papan tulis dan buku teks.

Isi skenario pembelajaran puisi rakyat dalam pelaksanaan Kurikulum 2013 di SMP Negeri 1 Sukasada dalam RPP sudah sesuai dengan komponen lampiran IV Permendikbud No. 81A Tahun 2013 tentang Implementasi Kurikulum Pedoman Umum Pembelajaran, khususnya pada bagian kegiatan pendahuluan, inti, dan penutup. Namun, pada tahap pelaksanaan pembelajaran masih ada beberapa tahapan kegiatan pelaksanaan yang belum sesuai dengan RPP maupun Permendikbud No. 81A Tahun 2013. Tidak hanya itu pemberian materi pada kegiatan pembelajaran puisi rakyat juga masih belum maksimal.

Materi yang diajarkan oleh guru selama melaksanakan kegiatan pembelajaran lebih dominan memberikan materi pantun daripada materi gurindam dan syair. Hal itu juga diperkuat oleh hasil wawancara 
dengan guru yang bersangkutan. Guru menyatakan bahwa materi pantun lebih sering diajarkan karena materi ini lebih mudah dipahami oleh siswa. Berdasarkan pernyataan tersebut, guru seharusnya mengajarkan ketiga materi puisi rakyat secara optimal, karena pembelajaran ini sangatlah penting dalam melestarikan sastra lama yang hampir dilupakan oleh generasi muda. Senada dengan pendapat Sugiarto (2006: 19) yang menyatakan bahwa, sastra melayu klasik atau puisi rakyat merupakan khazanah kebudayaan Indonesia yang kini hampir dilupakan oleh generasi muda.

Selanjutnya mengenai kegiatan pembelajaran. Pada tahap ini merupakan tahap awal yang dilakukan oleh guru dalam melaksanakan pembelajaran. Pada tahap ini, penerapan yang dilakukan oleh guru sudah sesuai dengan Permendikbud No. 81A Tahun 2013 mengenai kegiatan pendahuluan. Pada kegiatan ini guru sudah memberikan pembelajaran yang ditunjukan untuk memfokuskan perhatian siswa agar berpatisipasi aktif dalam pembelajaran. Dalam hal ini, pada awal kegiatan pelajaran pemberian apersepsi yang dilakukan oleh guru merupakan salah satu cara guru untuk mengajak siswa aktif dalam mengikuti pelajaran.Apersepsi yang diberikan berupa pertanyaan atau video mengenai pengalaman siswa atau pengetahuan siswa sebelumnya dengan yang dipelajari. Hal tersebut sejalan dengan pendapat Slameto (2003: 35) mengenai apersepsi, bahwa setiap guru perlu menghubungkan pelajaran yang diberikan dengan pengetahuan yang telah dimiliki siswa atau pengalamannya. Dengan demikian, siswa memperoleh hubungan antar pengetahuan yang dimiliki dengan $\begin{array}{lcr}\text { pelajaran } & \text { yang diterimanya. } \\ \text { Sehingga } & \text { dalam } & \text { proses }\end{array}$ pembelajaran siswa akan mengingat kembali mengenai pembelajaran yang telah lalu dan dapat meningkatkan motivasi siswa untuk mengikuti pelajaran.

Langkah berikutnya pada kegiatan inti yaitu mengamati. Kegiatan ini belum terlaksana dengan baik sesuai Kurikulum 2013 diakarenakan pada tahap ini siswa lebih banyak mengamati penjelasan materi pelajaran yang disampaikan (ceramah) oleh guru.Dalam hal ini, pemberian teknik ceramah oleh guru sebenarnya baik digunakan namun jika teknik ceramah lebih dominan maka dapat memengaruhi hasil kemampuan siswa dalam belajar.Dalam hal ini, teknik ceramah sangatlah berpengaruh dalam kegiatan pembelajaran. Hal tersebut juga berpengaruh terhadap model pembelajaran yang digunakan oleh guru.

Guru dalam melaksanakan kegiatan pembelajaran semestinya menggunakan model discovery learning yang tercantum pada RPP. Tentunya model ini bertentangan jika menggunakan teknik ceramah yang dominan. Karena discovery learning merupakan sebuah pembelajaran yang tidak menyajikan langsung pelajaran yang diajarkan, tetapi mengarahkan siswa untuk menemukan sendiri materi pelajaran yang telah diinstruksikan sebelumnya oleh guru.

Selanjutnya pada kegiatan inti yang belum maksimal penerapannya yaitu pada kegiatan menanya. Pada kegiatan ini, siswa belum mampu menyiapkan pertanyaan untuk dirinya sendiri dan terkesan malumalu saat guru mempersilahkan siswa bertanya. Namun, siswa akan bertanya ketika mengalami kendala dalam mengerjakan tugas. Dalam hal ini tentunya guru tidak 
sepenuhnya disalahkan karena guru juga telah memberikan kesempatan untuk siswa bertanya. Hanya saja, yang perlu dikritisi disini yakni guru perlu memancing lagi antusias siswa untuk bertanya,seperti memberikan motivasi siswa untuk bertanya. Dengan pemberian motivasi, tentunya berpengaruh terhadap keberanian siswa untuk bertanya. Seperti yang dikatakan oleh Sardiman (2012:74) bahwa motivasi akan menyebabkan terjadinya suatu perubahan energi yang ada pada diri manusia, sehingga akan berlanjut dengan persoalan gejala kejiwaan, perasaan dan juga emosi, untuk kemudian bertindak atau melakukan sesuatu.

Selanjutnya, pada kegiatan mengumpulkan informasi dan mengolah informasi. Siswa diberikan kesempatan berdiskusi secara berkelompok atau sistem teman sebangku untuk memahami dan menganalisis teks puisi rakyat. Pada tahap ini, siswa melakukan analisis terhadap teks puisi rakyat berupa pantun atau gurindam kemudian mengaitkan hasil analisis dengan teori yang telah mereka dapatkan.

Pada tahap berikutnya yaitu mengomunikasikan, siswa diberikan kesempatan untuk menyampaikan hasil diskusinya. Namun, pada tahap ini guru kurang memberikan penguatan atau apresiasi kepada siswa setelah siswa melakukan presentasi atau menjawab pertanyaan yang diberikan oleh guru. Dalam hal ini, seharusnya guru lebih sering memberikan respon atau penguatan pada siswa ketika menjawab atau bertanya. Sejalan dengan lampiran Permendikbud Nomor 22 Tahun 2016 bahwa guru sebaiknya membemberikan penguatan dan umpan balik terhadap respon dan hasil belajar siswa selama proses pembelajaran berlangsung.

Sesuai dengan pendapat
Hasibuan (2009: 73) yang
menyatakan bahwa, menutup
pelajaran adalah kegiatan guru
untuk mengakhiri kegiatan inti
pelajaran. Pada pelaksanaan
pembelajaran puisi rakyat, kegiatan
penutup yang dilakukan oleh guru
penerapannya masih kurang
maksimal. Kegiatan ini jarang
terlaksana disebabkan oleh
keterbatasan waktu dan

kesempatan. Akibatnya, serangkaian kegiatan penutup tersebut juga tidak dapat dilaksanakan oleh guru. Hal itu utamanya tampak pada kegiatan penyimpulan materi dan penilaian (refleksi) secara langsung.

Hasil penelitian ini sejalan dengan hasil penelitian yang dilakukanoleh Maghfiroh (2017)dengan judul "Pelaksanaan Pembelajaran Teks Puisi Rakyat Kelas VII di SMP Negeri 8 Yogyakarta". Hal yang serupa adalah pendekatan saintifik yang digunakan oleh guru dan metode yang digunakan oleh guru. Hasil penelitian Maghfiroh menyatakan guru dalam melaksanakan kegiatan pembelajaran menggunakan pendekatan saintifik yang meliputi kegiatan mengamati, menanya, mencoba, mengasosiasi, dan mengomunikasikan. Sedangkan metode yang digunakan oleh guru yaitu metode discovery learning/inkuiri dan PBL (Project Based Learning). Namun adanya perbedaan dengan hasil observasi yang peneliti lakukan yaitu hanya metedo discovery learning yang digunakan oleh guru pada pelaksanaan pembelajaran puisi rakyat.

ini Temuan kedua pada penelitian penggunaan teks. Penggunaan teks yang dilakukan oleh peneliti di SMP Negeri 1 Sukasada sudah disesuaikan dengan empat tahapan 
pembelajaran bahasa Indonesia berbasis teks berdasarkan Kemendikbud (2013: vi) yang meliputi (1) Tahap pembangunan konteks, (2) Tahap pemodelan teks, (3) Tahap pembuatan teks secara bersama-sama, dan (4) Tahap pembuatan teks secara mandiri.

Tahap pembangunan konteks, merupakan tahap awal dalam mengarahkan atau membangun pemahaman siswa mengenai pokok persoalan yang dibahas dalam pembelajaran.Hal tersebut sejalan dengan Kemendikbud (2013: vi) yang menyatakan bahwa, pembangunan konteks dimaksudkan sebagai langkah awal guru bersama siswa untuk mengarahkan pemikiran ke dalam pokok persoalan yang dibahas pada setiap pembelajaran.

Tahap pemodelan teks pada pembelajaran puisi rakyat sudah sesuai dengan teori yang ada pada tahap pemodelan tekssesuai dengan Kemendikbud (2013: vi). Setiap unsur yang ada pada materi menelaah model sudah terlaksana sesuai dengan teorinya, mulai dari tahap pertama sampai terakhir

Tahapan pembuatan teks secara bersama-sama. Pada tahap ini hanya pertemuan pertama, kedua, dan keempat yang bisa terlaksana. Hal tersebut dikarenakan pada pertemuan ketiga guru menugaskan siswa dari awal hingga akhir pelajaran untuk mengerjakan tugas secara mandiri. Pada tahap ini seperti biasa guru menugaskan siswa untuk duduk berkelompok dalam mendiskusikan tugas yang diberikan. Kemudian guru bertugas membimbing siswa jika mengalami kendala.Tahap pembuatan teks secara bersama-sama yang dilaksanakan di kelas VIIE SMP Negeri 1 Sukasada sudah sesuai dengan Kemendikbud (2013: vi) yang menyatakan, bahwa pada tahap pembuatan teks secara bersama-sama harus dilaksanakan secara bersama-sama oleh siswa dengan bimbingan dari guru.

Tahap terakhir penggunaan teks adalah pembuatan teks secara mandiri. Pada tahap ini hanya pertemuan pertama, kedua, dan keempat yang tidak terlaksana dikarenakan kehabisan waktu. Namun pada pertemuan ketiga kegiatan ini terlaksana, guru menugaskan siswa untuk menelaah gurindam secara mandiri. Hal tersebut sesuai dengan Kemendikbud (2013: vi) bahwa pada kegiatan mengontruksi mandiri siswa diharapkan dapat mengaktualisasikan diri dengan menggunakan dan mengkreasikan teks sesuai dengan jenis dan ciri-ciri seperti yang ditunjukan pada model.

Hasil penelitian ini sejalan dengan hasil penelitian yang dilakukan oleh Suryani (2014) dengan judul "Pembelajaran Bahasa Indonesia Berbasis Teks di Kelas $X$ SMA Negeri 1 Singaraja". Hal yang serupa adalah penggunaan empat tahapan pembelajaran bahasa Indonesia berbasis teks berdasarkan Kemendikbud. Hasil penelitian Suryani menyatakan pelaksanaan pembelajaran sebagian besar sudah dilaksanakan sesuai isi skenario pembelajaran. Empat tahapan pembelajaran bahasa Indonesia berbasis teks berdasarkan Kemendibud cenderung sudah tampak dalam pelaksanaan pembelajaran. Sama halnya dengan penelitian ini penggunaan teks dengan empat tahapan berbasis teks sudah tampak pada kegiatan pembelajaran puisi rakyat walaupun kurang maksimal penerapannya.

Temuan ketiga, penggunaan media pembelajaran puisi rakyat pada pelaksaan Kurikulum 2013. Media utama yang digunakan guru dalam pembelajaran puisi rakyat adalah teks. Teks puisi rakyat 
merupakan sarana untuk mempermudah penyampaian materi dan dapat merangsang siswa untuk belajar dengan baik. Media teks yang digunakan yaitu berbagai macam pantun dan gurindam yang diambil dari buku pegangan siswa.

Tidak hanya dari buku pegangan siswa, guru menyusun sendiri teks yang digunakan sebagai media dalam pembelajaran berupa lembar kerja siswa (LKS). Hal ini menunjukan bahwa guru telah berusaha untuk memberikan teks secara kontekstual kepada siswa. Kekontekstualan teks sangat berpengaruh terhadap proses dan hasil pembelajaran siswa. Sejalan dengan pendapat yang disampaikan oleh Sujana (2014) yang menyatakan bahwa, pembelajaran yang kontekstual membuat siswa menjadi tidak kesulitan dalam memahami isi pembelajaran. Hal tersebut dapat membuat siswa lebih mengingat materi pembelajaran sehingga dapat mempengaruhi hasil belajar yang diperoleh.

\section{Pada}

pelaksanaan pembelajaran guru tidak hanya menggunakan media teks tetapi juga menggunakan media lain sebagai media pendukung seperti papan tulis, Kamus Besar Bahasa Indonesia (KBBI), dan video di handphone. Media papan tulis merupakan salah satu media visual yang digunakan oleh guru untuk menuliskan topik dan kegiatan pembelajaran. Selain itu, papan tulis juga digunakan oleh guru untuk memperjelas materi pembelajaran yang belum dipahami oleh siswa.

Media Kamus Besar Bahasa Indonesia (KBBI) merupakan salah satu media visual yang digunakan siswa dalam pembelajaran menelaah ciri kebahasaaan apabila menemukan kata yang sukar. Dengan demikian, media KBBI dapat membantu siswa dalam mencari makna kata yang sukar dalam puisi rakyat yang sedang ditelaah. Penggunaan media kamus pada kegiatan pembelajaran dapat meningkatkan keaktifan siswa dalam mengikuti pelajaran. Senada dengan pendapat Arsyad (2009: 9) yang menyatakan bahwa, media berfungsi untuk tujuan instruksi yaitu informasi yang terdapat dalam media itu harus melibatkan siswa yang aktif, baik dalam benak atau mental maupun dalam bentuk aktivitas yang nyata sehingga pembelajaran dapat terjadi.

Selanjutnya, media terakhir yang digunakan guru adalah media video melalui Handphone. Media ini merupakan salah satu media audiovisual yang digunakan guru dalam memberikan contoh rekaman video pantun bersahut-sahutan yang dilakukan oleh siswa kelas VIIF. Namun memberikan video dengan menggunakan handphone tidaklah tepat. Dalam hal ini, akan mempersulit siswa dalam mengamati contoh yang diberikan. Seharusnya media pada umumnya merupakan sarana yang memberikan kemudahan bagi guru dalam mengajar dan bagi siswa dalam memahami. Maka penggunaan media yang tepat sangatlah berpengaruh dalam meningkatnya proses pembelajaran. Hal tersebut diperkuat oleh pendapat Arsyad (2009: 29) yang menyatakan bahwa, media pembelajaran berfungsi memperjelas penyajian pesan dan informasi sehingga dapat memperlancar dan meningkatkan proses dan hasil belajar. Berdasarkan hal tersebut, guru haruslah memilih media yang tepat dan bisa digunakan agar pembelajaran menjadi efektif dan efesien.

Hasil penelitian ini sejalan dengan hasil penelitian yang dilakukan oleh Nuarita (2016) 
dengan judul "Penggunaan Media Pembelajaran Bahasa Indonesia di SMP Negeri 2 Mlati". Hal yang serupa adalah penggunaan media dalam kegiatan pembelajaran menggunakan media visual dan audiovisual. Hasil penelitian Nuarita menyatakan pemilihan jenis media di SMP 2 Mlati disesuaikan dengan materi yang diajarkan oleh guru. Media yang digunakan berupa media visual dan audiovisual. Media visual yang digunakan oleh guru merupakan media yang sudah tersedia di kelas dan sengaja dipersiapkan oleh guru. Sedangkan media audiovisual yang digunakan guru merupakan fasilitas alat bantu yang tersedia di kelas seperti tape recorder dan speaker. Namun adanya perbedaan dengan hasil observasi yang peneliti lakukan yaitu bahwa penggunaan media audiovisual yang digunakan oleh guru merupakan alat bantu yang guru bawa sendiri berupa video melalui handphone.

Penelitian ini kajiannya sebatas pada pelaksanaan pembelajaran, penggunaan teks, dan penggunaan media dalam pembelajaran puisi rakyat pada pelaksanaan Kurikulum 2013. Yang belum dikaji pada penelitian ini yaitu mengenai penilaian pembelajaran, kendala-kendala dan respons siswa dalam pembelajaran puisi rakyat pada pelaksanaan Kurikulum 2013. Hal ini dapat menjadi peluang bagi peneliti lain untuk melanjutkan penelitian ini.

\section{SIMPULAN DAN SARAN}

\footnotetext{
Berdasarkan hasil dan pembahasan yang dipaparkan di atas dapat disimpulkan beberapa hal sebagai berikut.Pelaksanaan pembelajaran puisi rakyat dalam pelaksanaan Kurikulum 2013 di kelas VIIE SMP Negeri 1 Sukasada
}

belum sesuai dengan Permendikbud No. 81A Tahun 2013. Hal tersebut terlihat pada kegiatan inti dan penutup. Pada kegiatan inti pada saat mengamati, guru lebih sering memberikan teknik ceramah sehingga siswa dalam hal mengamati, lebih banyak mengamati penjelasan yang diberikan oleh guru. Pada kegiatan menanya, siswa di dalam pembelajaran kurang aktif bertanya, sehingga proses pembelajaran pada kegitan inti tersebut belum sesuai dengan Permendikbud No 81A Tahun 2013.

Pada kegiatan penutup sama seperti kegiatan inti belum sesuai karena pada kegiatan ini guru jarang menyimpulkan atau memberikan penilaian mengenai hasil kegiatan pembelajaran yang dilaksanakan. Selain itu, materi pembelajaran yang diberikan belum maksimal diajarkan karena guru lebih banyak mengajarkan materi pantun daripada syair dan gurindam.

Penggunaan teks pada pembelajaran puisi rakyat dalam pelaksanaan Kurikulum 2013 di kelas VIIE SMP Negeri 1 Sukasada belum sesuai dengan empat tahapan pembelajaran berbasis teks pada umumnya. Hal tersebut terlihat pada tahap pembuatan teks secara mandiri, kegiatan tersebut belum terlaksana dengan baik dikarenakan kehabisan waktu dalam melaksanakan pembelajaran. Itu berarti guru belum mampu mengelola waktu.

Penggunaan media pada pembelajaran puisi rakyat dalam pelaksanaan Kurikulum 2013 di kelas VIIE SMP Negeri 1 Sukasada masih sangat terbatas bahkan tidak sesuai dengan tuntutan Kurikulum 2013. Hal itu, karena guru dalam memberikan media lebih banyak 
menggunakan media papan tulis dan buku teks.

Berdasarkan pemaparan hasil penelitian dan simpulan, saran yang dapat disampaikan dalam penelitian ini adalah sebagai berikut. Hasil temuan pada penelitian ini menunjukan pelaksanaan, penggunaan teks, dan penggunaan media di SMP Negeri 1 Sukasada belum berjalan dengan baik sesuai Kurikulum 2013. Peneliti menyarankan dalam melaksanakan kegiatan pembelajaran puisi rakyat hendaknya guru agar lebih memahami dan mempelajari secara intensif mengenai Kurikulum 2013 sehingga dalam kegiatan pelaksanaan dan pemberian materi penerapannya agar sesuai dengan tuntutan Kurikulum 2013.

\section{DAFTAR PUSTAKA}

Arsyad, Azhar. 2009. Media Pembelajaran. Jakarta: PT Raja Grafindo Persada

Asyhar, Rayandra. 2012. Kreatif Mengembangkan Media Pembelajaran. Jakarta: Referensi Jakarta.

Harsiati, Trianto dan Kosasih. 2016. Bahasa Indonesia SMP Kelas VII. Pusat Kurikulum dan Perbukuan, Balitbang, Kemdikbud.

Hasibuan, J.J, Dkk. 2009. Proses Belajar Mengajar. Bandung: PT Remaja Rosdakarya.

Kemendikbud. 2013. Buku Siswa: Bahasa Indonesia Ekspresi Diri dan Akademikuntuk kelas $X$. Jakarta: Kementerian Pendidikan dan Kebudayaan.
Maghfiroh, Azizatul. 2017. Pelaksanaan Pembelajaran Teks Puisi Rakyat Kelas VII di SMP Negeri 8 Yogyakarta. Universitas Yogyakarta: Pendidikan Bahasa dan Sastra Indonesia.

Mahsun M.S. 2013. Teks dalam Pemebelajaran Bahasa Indonesia (Kurikulum 2013). Jakarta: PT Raja Grafindo Persada.

Midiastini, Ni Ketut. 2014. "Pelaksanaan Pembelajaran Bahasa Indonesia dengan Pendekatan Tematik Berdasarkan Kurikulum 2013 pada Kelas 4 SD Saraswati 1 Denpasar". Tesis (tidak diterbikan). Singaraja: Jurusan Pendidikan Program Pascasarjana Universitas Pendidikan Ganesha.

Nuarita, Finta. 2016. Penggunaan Media Pembelajaran Bahasa Indonesia di SMP Negeri 2 Mlati. Universitas Yogyakarta. Pendidikan Bahasa dan Sastra Indonesia.

Permendikbud No. 81A Tahun 2013 Tentang Implementasi

Kurikulum Pedoman Umum Pembelajaran. Jakarta.

Salinan Lampiran Peraturan Menteri Pendidikan dan Kebudayaan Nomor 22 Tahun 2016 tentang Standar Proses Pendidikan Dasar dan Menengah. Tersedia di

http://ainamulyana.blogspot.co.i d/ 2019/05/ downloadpermendikbud-n0-20-tahun2019_14.html? $\mathrm{m}=1$ (diakses tanggal 15/02/2019 
Sudirman. 2011. Interaksi dan Motivasi Belajar Mengajar. Jakarta: Raja Grafindo Persada.

Sugiarto, Eko. 2006. Mengenal Pantun dan Puisi Lama. Yogyakarta: Pustaka Widyatama.

Sujana, A. 2014. Pendidikan Ipa. Bandung: Rizqi Press.

Suryani, Putu. 2014. Pembelajaran Bahasa Indonesia Berbasis Teks Di Kelas X SMA Negeri 1 Singaraja. Singaraja: Undiksha.

Slameto. 2003. Belajar \& Faktor Faktor yang Mempengaruhinya. Jakarta: Rineka Cipta.

Wendra, I Wayan. 2011. Buku Ajar Penulisan Karya IImiah. Singaraja: Undiksha. 